\title{
Republic of Azerbaijan: Report on the Observance of Standards and Codes- Data Module, Response by the Authorities, and Detailed Assessment Using the Data Quality Assessment Framework (DQAF)
}

This Report on the Observance of Standards and Codes on Data Module for the Republic of Azerbaijan was prepared by a staff team of the International Monetary Fund as background documentation for the periodic consultation with the member country. It is based on the information available at the time it was completed on July 21, 2008. The views expressed in this document are those of the staff team and do not necessarily reflect the views of the government of the Republic of Azerbaijan or the Executive Board of the IMF.

The Response by the Authorities to this report, and the Detailed Assessments Using the Data Quality Assessment Framework (DQAF) are also included.

The policy of publication of staff reports and other documents by the IMF allows for the deletion of market-sensitive information.

Copies of this report are available to the public from

International Monetary Fund $\bullet$ Publication Services

700 19th Street, N.W. • Washington, D.C. 20431

Telephone: (202) $6237430 \bullet$ Telefax: (202) 6237201

E-mail: publications@imf.org • Internet: http://www.imf.org

Price: $\$ 18.00$ a copy

\section{International Monetary Fund Washington, D.C.}



INTERNATIONAL MONETARY FUND

AZERBAIJAN

\title{
Report on the Observance of Standards and Codes (ROSC)_Data Module
}

\author{
Volume I \\ Prepared by the Statistics Department \\ Approved by William E. Alexander and Mohsin S. Khan
}

July 21, 2008

This Data Module of the Report on the Observance of Standards and Codes (ROSC) provides an assessment of Azerbaijan's macroeconomic statistics against the Special Data Dissemination Standard (SDDS) complemented by an assessment of data quality based on the IMF's Data Quality Assessment Framework (DQAF), July 2003. The DQAF lays out internationally accepted practices in statistics, ranging from good governance in dataproducing agencies to practices specific to datasets.

The dataset covered in this report is the consumer price index. The agency that compiles the dataset assessed in this report is the State Statistical Committee (SSC).

The datasets to which this report pertains can be accessed in print and on the Internet:

SSC: http://www.azstat.org/indexen.php

This report is based on information provided prior to and during a mission that took place during February 11-22, 2008 and publicly available information. The mission comprised Mr. Kimberly D. Zieschang. 


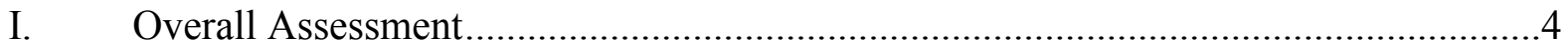

II. Assessment by Agency and Dataset ................................................................

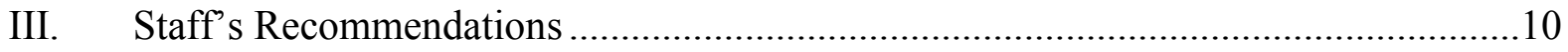

Tables

1. DQAF July 2003 - Summary Results.................................................................

2. Assessment of Data Quality-Dimensions 0 and 1-State Statistical Committee ...........8

3. Assessment of Data Quality-Dimensions 2 to 5-Consumer Price Index .....................9

Appendix Table

4. Azerbaijan: Practices Compared to the SDDS Coverage, Periodicity, and Timeliness of Data 


\section{ACRONYMS}

1993 SNA

COICOP

CPI

CPI Manual

DQAF

DSBB

GDDS

HBS

ROSC

SDDS

STA
System of National Accounts 1993

Classification of Individual Consumption by Purpose

Consumer Price Index

Consumer Price Index Manual 2004

Data Quality Assessment Framework

Dissemination Standards Bulletin Board

General Data Dissemination System

Household Budget Survey

Report on the Observance of Standards and Codes

Special Data Dissemination Standard

IMF Statistics Department 


\section{Overall ASSESSMent}

1. Azerbaijan began participation in the General Data Dissemination System (GDDS) on July 6, 2001, with metadata posted on the Dissemination Standards Bulletin Board (DSBB). Azerbaijan's Consumer Price Index (CPI) meets Special Data Dissemination Standard (SDDS) specifications for coverage, periodicity, and timeliness. Appendix Table 4 provides an overview of Azerbaijan's dissemination practices for the CPI compared with the SDDS.

2. This Report on the Observance of Standards and Codes (ROSC) data module covers consumer price statistics. This report assesses this dataset against the requirements of the SDDS using the July 2003 version of the IMF's Data Quality Assessment Framework (DQAF). It is a reassessment of the CPI component of the data module for Azerbaijan conducted in 2002 against the recommendations of the GDDS on the basis of the July 2001 version of the DQAF. In the interval since the last assessment, practices have been strengthened in confidentiality, relevance, professional independence, transparency, classification, source data, statistical techniques, cross-dataset consistency, and metadata accessibility. Applying the more demanding standard of the most recent version of the DQAF against the broadly improved statistical practices of the CPI has changed somewhat the pattern of the assessments for the CPI in this ROSC as compared with the 2002 ROSC.

3. The CPI is compiled and disseminated by the State Statistical Committee (SSC) within a strong legal and institutional framework and with adequate resources. The SSC is established at the center of the statistical system by the Law on Official Statistics (as amended October 20, 2006) and the Statute on the State Statistical Committee (November 24, 2005). The SSC has broad data collection, data sharing, and coordination functions and powers in the statistical domain. Confidentiality of individual reporters' information is strongly supported in law and practice. The CPI statistical program has adequate resources, including staff to achieve its objectives, and is directed by a five-year Program of Statistical Development and an annual Program of Statistical Work covering all SSC statistical products that are approved at the executive levels of government. Concerning relevance, the legal and institutional framework in place since 2006 provides a solid basis for user feedback with the creation of a broadly-representative Statistical Council. The Council is charged with taking user concerns into account in its already functioning and legally sanctioned consultative role to the SSC in determining the five-year Program of Statistical Development and Annual Program of Statistical Work. The minutes of the Council's meetings are available on request, and it may express its views to the public.

4. Foreshadowing the assessment below, the mission considers that the CPI currently is a methodologically sound and reliable inflation indicator, but there is scope to maintain the relevance of the CPI by taking sustained action to address user concerns about how well it measures inflationary pressure. Based on its current channels of information, the SSC believes that most users give greatest attention to the level and importance in the index of inflation in basic goods and services in the CPI, such as food. A recent user issue has concerned how well the CPI represents, and combines into the national index, the regional price developments in Azerbaijan. Looking ahead, the treatment of housing may need further examination in view of recent economic developments. 
5. In applying the IMF's DQAF, the remainder of this section presents the mission's main conclusions. The presentation is done at the level of the DQAF's quality dimensions, focusing on the SSC for the first two dimensions and on the CPI dataset for the remaining four.

6. Production of the CPI is well supported by ample assurances of integrity. Section IV of the Law on Official Statistics guarantees the professional independence of the SSC and Article 10 provides the statutory basis for independently selecting sources and methods. The SSC has responded, as appropriate, to specific criticism of its estimates by external users, usually through the news media, under its obligations set out in Article 6 of the Law. The Law on Official Statistics and the Statute on the State Statistical Committee specify comprehensively the terms and conditions under which statistics are collected, processed and disseminated, and are posted in Azerbaijani and English on the SSC website. The monthly $\mathrm{CPI}$ figures are released to all users simultaneously via the SSC website. All outputs of the SSC are clearly identified as such, including in republication of its CPI data on the website of the National Bank of Azerbaijan. The SSC gives users a one-month advance reminder of its annual update for CPI weights in its statistical bulletin, and a one-month advance notice of updates to the CPI item list, as required. Ethical standards of behavior are well established in law and well known to the staff.

7. The concepts and definitions are generally in line with international standards and guidelines as defined in the System of National Accounts 1993 (1993 SNA) and Consumer Price Index Manual 2004 (CPI Manual). The CPI meets scope requirements. Included institutional units and transactions are broadly in line with the 1993 SNA. The Classification of Individual Consumption by Purpose (COICOP) has been used in the Household Budget Survey (HBS) since 2002 and the CPI since 2003.

8. The CPI has good data sources for both weights and prices. These are based on welldesigned household and retail establishment surveys with comprehensive coverage of their target populations, well matched to the concepts and definitions selected for the index, and having sufficient detail by geographical area and category of household expenditure. The surveys produce commendably timely data. HBS data for weights are available by February following the most recent survey year, and price data are in by the fifth of the month after the survey month. Since 2007, HBS expenditure data have been used for the weighting of the $\mathrm{CPI}$ survey regions within the economic regions, as well as combining the 11 economic regions into the national index. The goods and services detail of the CPI weights is adequate, with product specifications sufficiently narrow and well described to enable monthly comparison of prices of the same set of items. The index is annually rebased, and a short description of products increasing and decreasing in weight is provided to users in the monthly bulletin. However, the CPI expenditure weight for the expenditures on housing services by households owning their own dwellings deviates from the imputed rentals concept in household final consumption expenditure. Measuring asset prices for housing is noted in the CPI Manual as a complementary approach to measuring imputed rentals of housing services for owner-occupants. Given the lack of information in this area, the mission suggests that an expert group study and propose options for improving the measure of housing consumption prices and developing a measure of housing asset prices. 
9. The CPI periodicity and timeliness meet and exceed SDDS requirements, respectively. The monthly index is usually published by the $10^{\text {th }}$ of the month following the survey month. It is internally consistent and tracks other SSC price indexes well when matched item for item. The expenditure coverage in the CPI dataset is fully consistent with household final consumption expenditure coverage in the national accounts dataset - apart from owner-occupied dwellings. Both incorporate the National Accounts Division's adjustment of comparable aggregates from the HBS using selected totals from the retail trade survey and certain adjustments that correct for specific items thought to be under-reported by households on the HBS.

10. Accessibility of the CPI follows good practices regarding availability of metadata and assistance to users. Data accessibility meets or exceeds SDDS periodicity and timeliness. Advance notice of CPI releases can be inferred from the prescribed maximum publication lags in the Annual Statistical Program, and the SSC has posted a sample SDDS advance release calendar on its website. However, the advance release calendar did not contain release dates for at least the next three months at the time of the mission, and is not updated from a "not later than" date to an exact date by the last business day of the week preceding the release.

11. Section II provides a summary assessment based on a four-part scale. This is followed by staff recommendations in Section III. Practices compared to the SDDS are summarized in Appendix Table 4. The authorities' response to this report and a volume of detailed assessments are presented in separate documents.

\section{ASSessment by AgenCy and Dataset}

12. Assessment of the quality of the CPI was conducted using the DQAF, July 2003. In this section, the results are presented at the level of the DQAF elements and using a fourpoint rating scale (Table 1). Assessments of the prerequisites of data quality and the assurances of integrity (Dimensions " 0 " and " 1 " of the DQAF) are presented in Table 2 . The assessment of methodological soundness, accuracy and reliability, serviceability, and accessibility (Dimensions " 2 " to " 5 " of the DQAF) are shown in Table 3. 


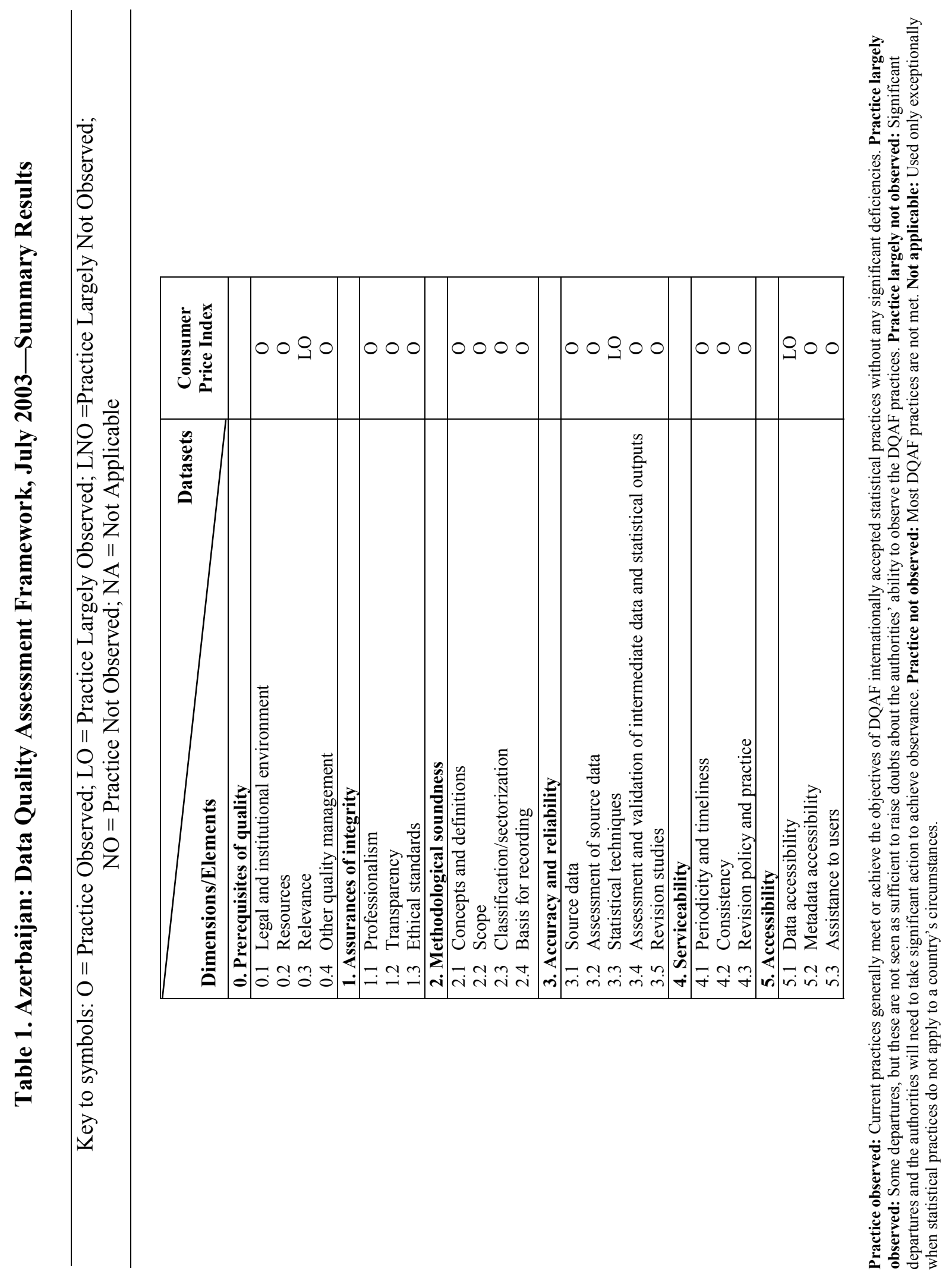




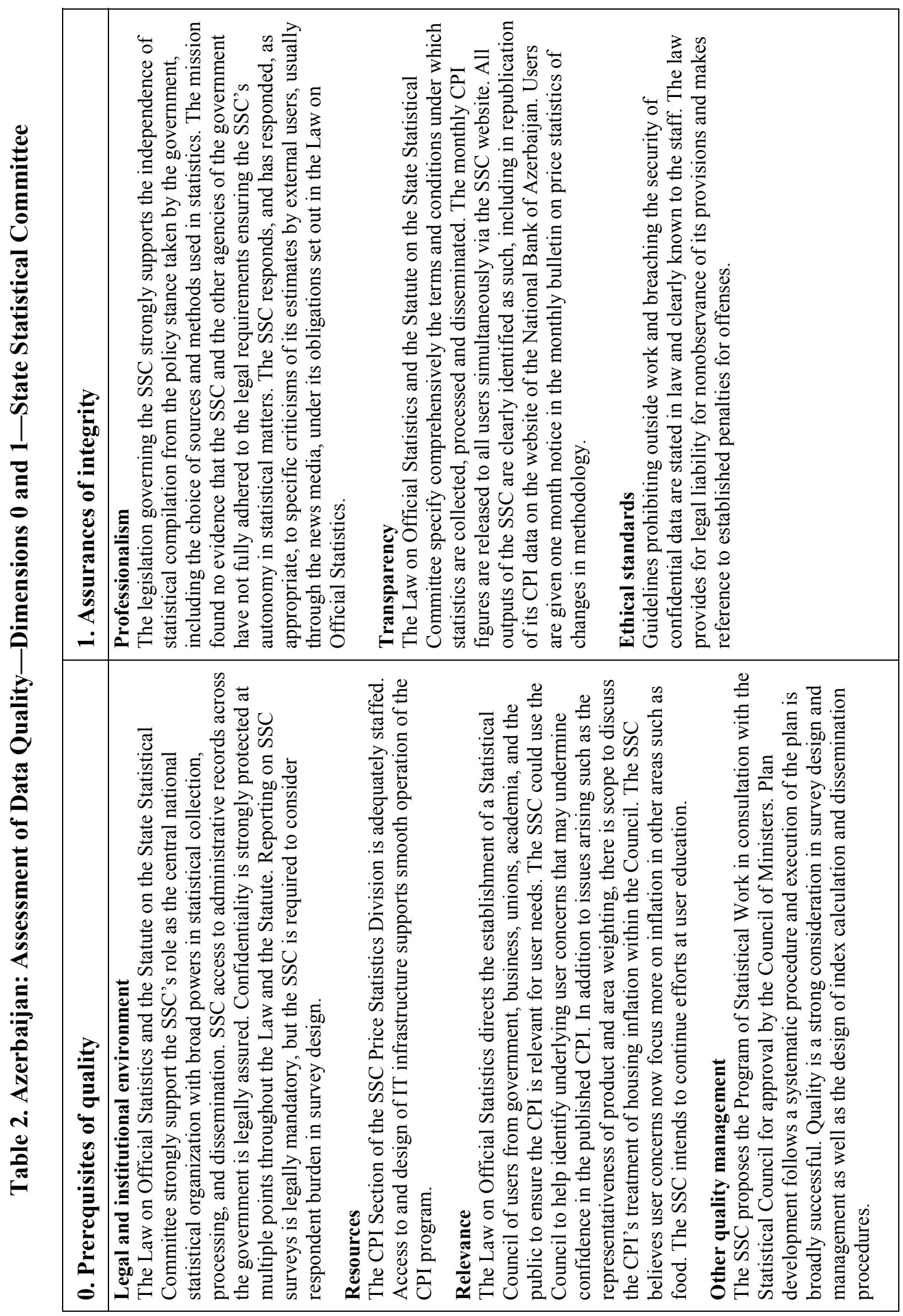




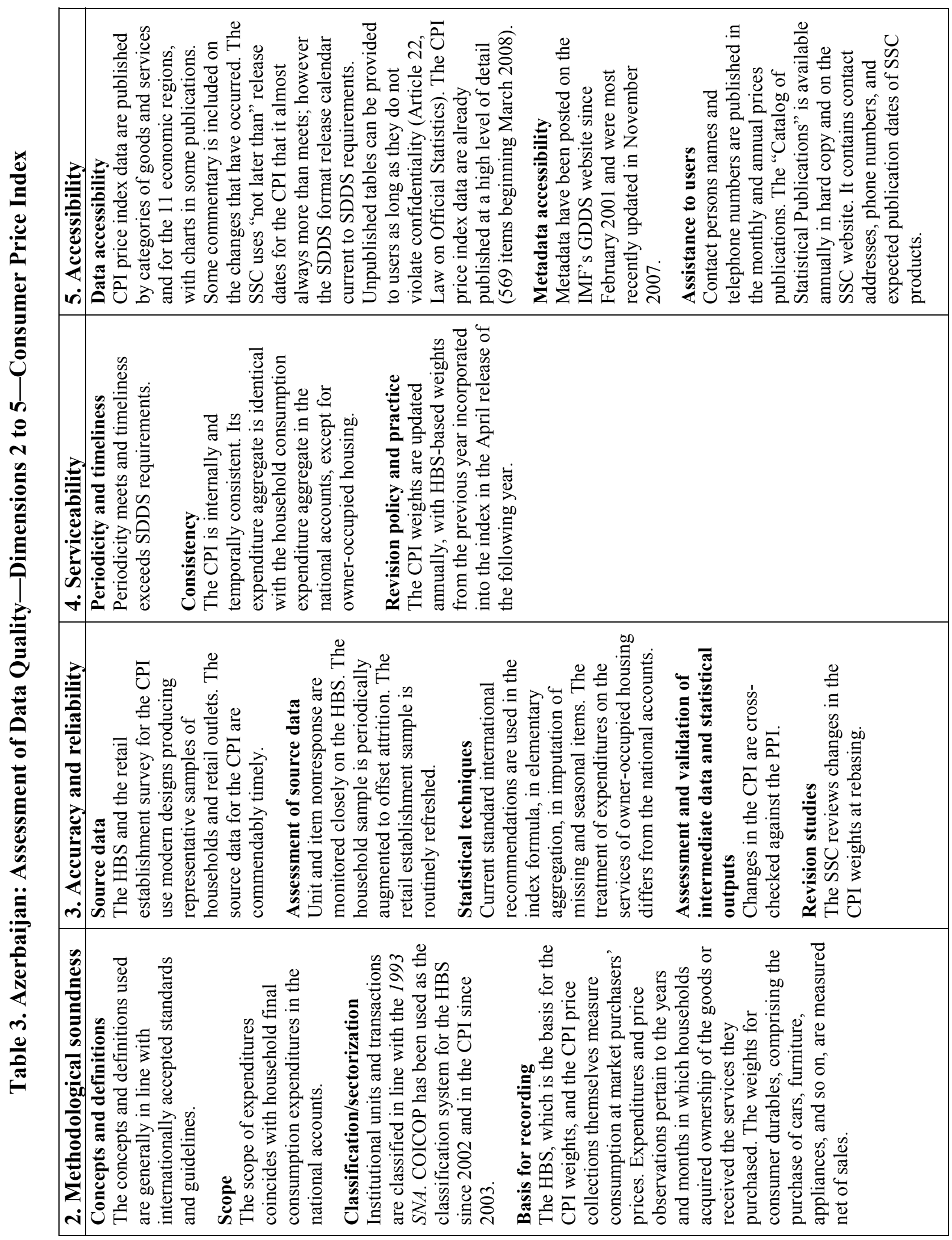




\section{STAFF's RECOMMENDATIONS}

13. Based on the review of statistical practices, discussions with the data producing agencies, and responses from data users (see Appendix III of the Detailed Assessments volume), the mission has developed a set of recommendations. They are designed to increase further adherence to internationally accepted statistical practices and would, in the mission's view, enhance the analytical usefulness of the CPI. Some additional technical suggestions are included in the Detailed Assessments volume.

- $\quad$ The SSC could use the recently-formed Statistical Council more proactively to help identify and address users' concerns in order to foster confidence in the published CPI.

- The Council would be a good forum to inform users about the impacts of the SSC's confidentiality policy. To provide a margin of error in ensuring that its disclosure rules are met, the SSC has had to limit the disseminated detail of the HBS expenditure information that is used for the CPI weights. At least one user did not understand the reason for this.

- The Council could be made aware of user concerns arising on, for example, the product and area weighting of the CPI, as well as any internal and external assessments of such issues.

- The SSC also could propose discussion of forward-looking matters such as price indicators to meet new measurement needs with the Council

- $\quad$ The SSC should technically evaluate the rental equivalence and user cost approaches to covering the housing services consumption of households that own their dwellings and the net acquisitions approach to households' capital formation expenditures for dwellings. While collaboration between the Price Statistics Division, National Accounts Division, and Scientific-Methodology Council would be essential, a specific advisory expert group of SSC and outside experts on the topic of housing could be useful in the evaluation as well.

- $\quad$ Keeping the SDDS advance release calendar current and making this site known through user outreach could help improve user confidence in the transparency and professionalism with which the CPI is compiled, and would align this practice with SDDS requirements. 
Appendix Table 4. Azerbaijan: Practices Compared to the SDDS Coverage, Periodicity, and Timeliness of Data

\begin{tabular}{|c|c|c|c|c|c|c|}
\hline \multirow{2}{*}{$\begin{array}{c}\text { SDDS } \\
\text { Data } \\
\text { Category }\end{array}$} & \multirow{2}{*}{$\begin{array}{c}\text { Coverage } \\
\text { (meets SDDS } \\
\text { requirement) }\end{array}$} & \multicolumn{2}{|c|}{ Periodicity } & \multicolumn{2}{|c|}{ Timeliness } & \multirow[t]{2}{*}{ Comments } \\
\hline & & SDDS & Azerbaijan & SDDS & Azerbaijan & \\
\hline \multicolumn{7}{|l|}{ Real Sector } \\
\hline Consumer Price Index & Yes & M & M & $\begin{array}{c}\mathrm{M} \\
(\text { GDDS } 1-2 \mathrm{M})\end{array}$ & NLT 10d & - \\
\hline
\end{tabular}

Note: Periodicity and timeliness: (D) daily; (W) weekly or with a lag of no more than one week from the reference data or the closing of the reference week; (M) monthly or with a lag of no more than one month; (Q) quarterly or with a lag of no more than one quarter; (A) annually; and (...) not applicable.

Italics indicate encouraged categories. 


\section{INTERNATIONAL MONETARY FUND}

AZERBAIJAN

\section{Report on the Observance of Standards and Codes (ROSC)—Data Module}

\section{Volume II}

\section{Response by the Authorities}

July 21,2008

This document contains the authorities' response to the IMF's data quality assessment (Volumes I and III), and their agreement to the publication of the ROSC. 


\section{STATE STATISTICAL COMMITTEE OF AZERBAIJAN REPUBLIC}

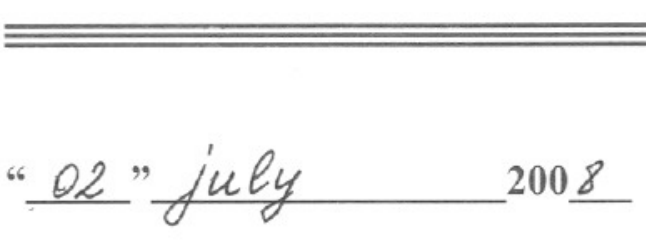

\section{Dear Mr. Robert W. Edwards,}

Please be informed that we have received and acquainted with Report on the Observance of Standards and Codec (ROSC) - Data Module (Volume I) and accompanying Detailed Assessment for the Consumer Price Index (Volume III), which was prepared based on data obtained during IMF mission to Baku on 11-12 February 2008.

We would like to express our sincere appreciation regarding to estimation CPI worked out by the State Statistical Committee. Please be informed that we agree with placement of the Report on the Observance of Standards and Codec (ROSC) - Data Module in the IMF web-page and IMF will be provided with new data on CPI in the future.

\section{Sincerely yours,}

Chairman

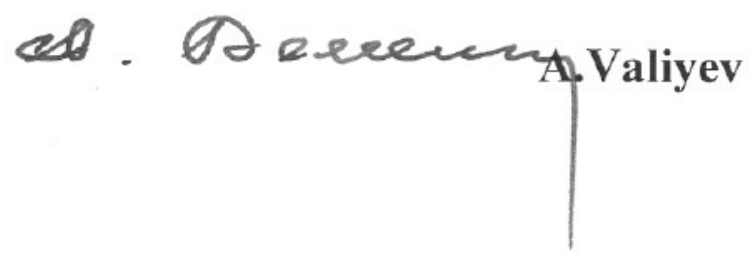


INTERNATIONAL MONETARY FUND

AZERBAIJAN

Report on the Observance of Standards and Codes (ROSC)—Data Module

Volume III

Detailed Assessment Using the Data Quality Assessment Framework (DQAF)

Prepared by the Statistics Department

Approved by William E. Alexander and Mohsin S. Khan

July 21,2008

This document contains a detailed assessment for the Consumer Price Index of the elements and indicators that underlie the data quality dimensions discussed in Azerbaijan's Report on the Observance of Standards and Codes (ROSC) Data Module. It also includes as appendices the DQAF generic framework and the results of the users' survey. 
Acronyms...... 3

I. Price Statistics (Consumer Price Index) ..... .4

Table

1. DQAF (July 2003): Summary of Results for Price Statistics (Consumer Price Index)...27

\section{Appendices}

I. Data Quality Assessment Framework - Generic Framework........................................28

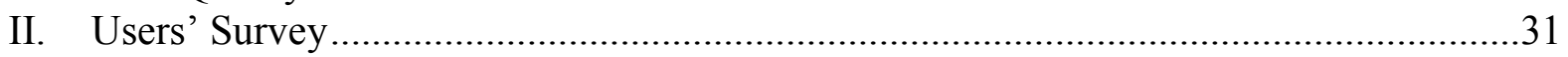




\section{ACRONYMS}

1993 SNA

COICOP

CPI

CPI Manual

DQAF

GDP

HBS

ILO

NBA

ROSC

SDDS

SNA

SSC

System of National Accounts 1993

Classification of Individual Consumption by Purpose

Consumer price index

Consumer Price Index Manual 2004

Data Quality Assessment Framework

Gross domestic product

Household Budget Survey

International Labor Organization

National Bank of Azerbaijan

Report on the Observance of Standards and Codes

Special Data Dissemination Standard

System of National Accounts

State Statistical Committee 


\section{Detailed Assessment Using the DAta QuAlity AsSessment Framework (DQAF)}

The following detailed information on indicators of statistical practices for consumer prices was gathered from publicly available documents and information provided by the Azeri officials. This information, which is organized along the lines of the generic DQAF (see Appendix I), was used to prepare the summary assessment of data quality elements, based on a four-part scale of observance, shown in Azerbaijan's Report on the Observance of Standards and Codes (ROSC)—Data Module.

\section{Price Statistics (Consumer Price Index)}

\section{Prerequisites of quality}

\subsection{Legal and institutional environment}

\subsubsection{The responsibility for collecting, processing, and disseminating the statistics is clearly specified.}

The consumer price index (CPI) is compiled and disseminated by the State Statistical Committee (SSC), which is governed by the Law on Official Statistics, as amended October 20, 2006. Article 3 of the Law on Official Statistics defines the institutional scope of the state statistical bodies as the SSC and the local statistical bodies, the latter being "obedient only to the SSC of Azerbaijan." Article 6 holds the state statistical bodies responsible for:

1. Preparing after consultation of the Statistical Council a draft of the Programme [of Statistical Works] in accordance with Article 3 of the Law, preparing, organising and the implementation of the statistical activities determined by the Programme;

2. Working out the methodology, classifications and standards being more comparable with standards accepted in international practice and methodical assistance for the production of official statistical materials and carrying out observations neatly that are entrusted to other authorities by this program;

3. Giving a yearly report on the implementation of the Programme to the Cabinet of Ministers and making this report available to the public;

4. Providing the executive powers of the Republic of Azerbaijan and its regions with the necessary socio-economic statistical information in accordance with the Programme of Statistics;

5. Compiling of results, summarizing and grouping on the basis of necessary data collected from reporting units in the Country and its regions, preparing statistical yearbooks, bulletins, reviews, press releases and other statistical materials, disseminating them among the users, publication of statistical data which are of interest of the public in the media; 
7. Guaranteeing the reliability and objectivity of statistical information, its accuracy in fully reflecting the socio-economic events and processes taking place, its level of quality and, as well as ensuring that it is up to date and does not violate statistical confidentiality;

8. Organising explanation of importance of Official Statistics to general public;

$\cdots$

10. Conducting and establishing the State Register of statistical units;

11. Preparing national classifications of necessary technical, economic and social information for organising the statistical works on the base of classifications applied in international practice and by taking into consideration the requirements of legislative acts of the Republic of Azerbaijan;

12. Introducing information of legal persons, government authorities or citizens upon their request about data, stored on them in statistical data bases;

13. Providing free of charge legal and natural persons who submit state statistical reports with questionnaires and instructions for their compilation, informing them about deadlines, periodicity of submission of reports and other requirements.

Paragraph 1 of the Statute on the State Statistical Committee (November 24, 2005) states:

The State Statistical Committee of the Republic of Azerbaijan (referred after to as the SSC of Azerbaijan) is the central executive authority running state policy in the field of statistics and forming official statistics on the social, economic and demographic situation of country on the base of unified methodology.

The Law on Official Statistics and the Statute on the State Statistical Committee designate the SSC as the central statistical organization with broad powers over the statistical domain of government operations, including collection, processing and dissemination of statistics.

\subsubsection{Data sharing and coordination among data-producing agencies are adequate.}

Article 7 of the Law on Official Statistics guarantees the SSC's access to administrative records and other data produced by legal entities. The class of units defined as legal entities has broad coverage, including government units other than the state statistical bodies, such as the ministries of the central government and the National Bank of Azerbaijan (NBA).

Important areas of statistics are covered by these other agencies, such as the NBA, which compiles monetary data and balance of payments statistics; the Ministry of Finance (MOF), which is responsible for compiling budget statistics; and the SCC, which compiles international merchandise trade data. The Law gives the SSC primary and coordinating roles in the development of the country's statistical program. The SSC maintains close contact with the other agencies. Administrate records and other data are obtained on a timely basis and at the required level of detail from the legal entities covered by Article 7. 
Regarding the CPI in particular, records from other agencies, such as the MOF, are used in updating the SSC business register, which is an important source of information used to construct and update the retail establishment sampling frame for the CPI outlet sample.

The interagency data sharing arrangements are strong and functional.

\subsubsection{Individual reporters' data are to be kept confidential and used for statistical purposes only.}

The Law on Official Statistics (as amended October 20, 2006) states the following regarding confidentiality of individual information reported to state statistical bodies (including the SSC and the regional statistical bodies):

The aim of Official Statistics is to increase the role of statistical data, to serve the interests of legal entities and natural persons by respecting their rights and keeping the confidentiality primary data.

The main aim of Official Statistics shall be to provide confidentiality of primary data depicting the socio-economic situation in the country, scientific and technological progress, economic links at country, regional and sector level, structural changes and efficiency of production, as well as to provide statistical information satisfying the needs of government bodies, economic agents and scientists. [Article 2. Aim of the Official Statistics in the Republic of Azerbaijan]

The state statistical bodies shall, within the limits of their competence, be responsible for: ...

7. Guaranteeing the reliability and objectivity of statistical information, its accuracy in fully reflecting the socio-economic events and processes taking place, its level of quality and, as well as ensuring that it is up to date and does not violate statistical confidentiality; [Article 6. Duties of the state statistical bodies]

The state statistical bodies shall be given the following rights and powers to perform their duties:

$\cdots$

3. To institute administrative procedures and apply administrative penalty measures to officials and natural persons failing to present data for Official Statistics or who submit them late or containing distortions and disseminate of information covered by statistical confidentiality; [Article 7. Rights and powers of the state statistical bodies]

In order to ensure the quality of Official Statistics and retain the trust of the public therein, the organisation and implementation of the Programme [of Statistical Works] shall be governed by the principles of reliability, objectivity, relevance in present situation, statistical confidentiality and transparency. [Article 9. Principles[of Official Statistics]

When implementing the Programme, the state statistical bodies are autonomous and shall not seek or take instructions from state and local bodies notably in the selection of data sources, statistical methods, in the contents, form and time of dissemination and in the application of statistical confidentiality. [Article 10. Autonomy of Offical Statistics] 
Statistical units involved in submitting information for the production of official statistical materials have the right to get information about the purpose of the survey and census, coverage and to be provided with the guarantee of confidentiality of data, as well as to get information about their authorities and duties. [Article 11. Statistical observations]

Section VI (Primary Statistical Data and its Confidentiality) of the Law on Official Statistics contains six articles defining and governing the use of primary (individual) records under the following topics:

Article 15. Primary statistical data and its use

Article 16. Statistical confidentiality and data from public sources

Article 17. Use of confidential statistical data

Article 18. Scientific research

Article 19. Access to confidential statistical data

Article 20. Protection measures

Article 22 (Dissemination of confidential statistical data) of the Law on Official Statistics sets a precise disclosure standard:

Official Statistics must not be disseminated to users, if they contain or reveal confidential data. To this end, aggregates shall comprise at least three units and the share of one unit in an aggregate must not exceed $85 \%$ of the total.

Article 26 (Responsibility for violating the legislation on statistics) states that:

Any violation of the legislation on statistics shall necessary entail disciplinary, administrative or criminal responsibility in accordance with the legislation.

Finally, Article 28 (Responsibility of staff of the state statistical bodies) of the Law on Official Statistics sets out liability for legal action against staff of state statistical bodies violating the confidentiality of individual records during or after their employment with those bodies.

Paragraph 6.5 of the Statute on the State Statistical Committee (November 24, 2005) requires the SSC to maintain confidentiality as a condition for providing users with data at the country, region, and city level, and paragraph 7.16 charges the SSC to carry out necessary measures to prevent obtaining, disseminating and using confidential statistical data contradicting the law.

Survey forms clearly state that reported data are subject to confidentiality under the Law. Staff are subject to dismissal should breaches of confidentiality occur, and they are required to sign a form on joining the SSC that confirms that they undertake not to disclose confidential data. Access to individual data is restricted to the appropriate staff, both as regards the actual forms and to the computer records. 
0.1.4 Statistical reporting is ensured through legal mandate and/or measures to encourage
response.

Article 6 of the Law on Statistics empowers the SSC to obtain data from registered economic units and households, including commercially confidential data. In cases of violation or noncompliance with the Law, Articles 15 and 16 provide for substantial penalties, including disciplinary, administrative or criminal sanctions. In order to encourage voluntary response, the SSC has reduced the reporting burden on small enterprises, and now requests data quarterly rather than monthly and for all respondents the total number of report forms has been reduced by over two thirds. Full assistance is available for respondents in completing questionnaires.

\section{$0.2 \quad$ Resources}

\subsubsection{Staff, facilities, computing resources, and financing are commensurate with statistical programs.}

The CPI section of the Price Statistics Division has one chief economist and one senior economist handling day-to-day operations and reporting to the Head of the Prices Division. The CPI establishment survey comprises 17 price collectors (registrars) in the Baku regional office, which supplies data on the Baku CPI region covering 11 districts. There are 85 additional price collectors in the 59 districts covering the remaining 53 CPI regions (the Nakhchivan region covers 7 districts). The central and regional office operations of the CPI program are supported by the computer center. Staff are trained in price collection procedures on a regular basis through internal seminars organized by the Price Statistics Division and the Statistical Information Division. The Price Statistics Division promotes staff participation in international training opportunities, including the training courses conducted by the IMF.

The SSC has a network of personal computers serving all professional staff of the CPI section, and has a modern, secure price database serving regional office collection and validation of prices, as well as central office retrieval and analysis of individual record information, to manage the price survey and compile statistics. The index calculation system is modern and its algorithms incorporate current international recommendations. The computer system serving the Household Budget Survey (HBS) is likewise modern and secure in storage of individual record information, and in retrieval of data for survey management, analysis, and compilation of statistics on households, including compilation of the CPI weights. 
Salary rates are reviewed annually and have been adjusted periodically to maintain the quality of recruited staff and limit staff turnover to levels sustaining the SSC's professional capacity to execute the CPI work program and develop its CPI statistical products. Price collectors receive transportation allowances to visit the retail establishments in their survey assignments.

\subsubsection{Measures to ensure efficient use of resources are implemented.}

The SSC Board (collegia), comprises the "Chairman of the SSC of Azerbaijan (Chairman of the Board), Deputy Chairmen by duties, as well as chairman of the State Statistical Committee of Nakhchivan Autonomous Republic, leading personnel of central office of the SSC of Azerbaijan and organizations of its obedience" (Statute on the State Statistical Committee, November 24, 2005). The Board is charged with supervising the organization of work and execution of the Program of Statistical Work approved by the Cabinet of Ministers of the Republic of Azerbaijan. The Board coordinates the activities of the various departments and gives advice on priorities, determines the requirements for adequate funding, establishes priorities concerning the collection of the data, and ensures that compatible methodologies, classifications and generally-accepted good statistical and management practices are followed within the SSC.

Article 3 of the Law on Official Statistics directs that:

The Programme shall cover the information obtained in the result of statistical observations to be organized concerning with studying the economic, demographic, social and environmental situation in the Republic of Azerbaijan, by taking existing resources, the burdens on respondents and the costeffectiveness into account.

Thus the Statistical Programme design must give attention to resource efficiency. Managers conduct periodic reviews of staff performance.

The decision to update the retail establishment sample continuously on the basis of information from price collectors rather than wait for a formal resampling procedure involving the business register is evidence that statistical processes are periodically reviewed to find opportunities to increase efficiency. The business register updates with a lag, so formal resampling may best be undertaken only every several years

\subsection{Relevance}

\subsubsection{The relevance and practical utility of existing statistics in meeting users' needs are monitored.}


Article 8 of the Law on Official Statistics of February 18, 1994, as amended October 20, 2006, establishes a Statistical Council of data users from the government, business, trade union, academic, and other social sectors that advises on the work program of the SSC:

The Statistical Council of the Republic of Azerbaijan (hereinafter referred to as the Council) is hereby established to give advice on the preparation and implementation of the Programme of Statistical work and on the development, organising and functioning of statistics and is connective between statistics and users. The Council acts on social base under the SSC of Azerbaijan. The Council performs notably the following functions:

- to give an opinion and to make recommendations on the preparation of the Programme;

- to give advice on the implementation of the Programme;

- to prepare recommendations for the systematic development of the system of Official Statistics in the Republic of Azerbaijan;

- to give appropriate recommendation to the SSC of Azerbaijan taking into consideration remarks, comments and purposes by user;

The work of the Council is public. It may address its opinions to the public.

The Council shall be composed of the representatives of the SSC of Azerbaijan, Ministries of Finance, Economic Development, Taxes, State Committee of Customs, National Bank, Trade Unions, private enterprises, academic society, and users.

The members of the Council shall be approved by a decision of the Cabinet of Ministers for a term of 5 years.

The Council meets quarterly and is the principal channel through which user needs influence SSC statistical products and its program of work.

The Statistical Council is an important institutional mechanism for making the SSC responsive to the needs of its data users. The Price Statistics Division would be involved in SSC management's preparation for the periodic Council meetings through the SSC Board (collegium) should a price issue be thought relevant for the agenda. This has not happened yet, and the Council has not yet been a significant source of user feedback on the CPI.

Legislation provides that the Council may address its opinions to the public. There may be unexploited opportunities for educating users through the Council meetings about products the SSC already produces that can meet the needs users express, or to explain why the SSC has decided not to meet certain user requests. An example of an agenda item covering the first subject would be any public controversy about the accuracy or credibility of SSC data series. An example of an agenda item covering the second subject might address an SSC decision not to release selected detailed data items. In the latter instance, these explanations may involve protecting the privacy of individual reporters, or a lack of staff capacity to handle the increased inquiries from the public that detailed releases sometimes engender. 
Recommendation: The SSC could use the recently-formed Statistical Council more proactively to help identify and address users' concerns in order to foster confidence in the published CPI. To provide a margin of error in ensuring its disclosure rules are met, the SSC limits the disseminated detail of the HBS expenditure information that is used for the CPI weights. At least one user did not understand the reason for this. The Council would be a good forum to inform users about the impacts of the SSC's disclosure policy. The Council could be made aware of issues arising on, for example, the product and area weighting of the CPI, as well as any internal and external assessments of such issues. The SSC also could propose discussion of forward-looking matters with the Council as well, such as the need for new price indicators, as required.

\section{$0.4 \quad$ Other quality management}

\subsubsection{Processes are in place to focus on quality.}

Management of the SSC emphasizes maximizing the quality of its statistical information products through the design of its statistical processes and motivation of the staff to execute those processes faithfully. This is demonstrated, for example, by the careful review of price changes - with particular attention paid to anything that looks unusual — prior to final index tabulation, and the strong focus on implementing and adhering to international best practice in price index compilation, as described, for example, in the Consumer Price Index Manual 2004 (CPI Manual). Product specifications are recorded and saved on the price database, and the survey forms price collectors use for recording prices from retail establishments are preprinted with the descriptions of the product specifications that are assigned by the survey to each establishment.

\subsubsection{Processes are in place to monitor the quality of the statistical program.}

The Statistical Council (see 0.3.1) is the principal source of fitness-for-use quality assessment information from users, and has a legally-sanctioned consultative role in SSC's development of the five-year Program for Development of Statistics and annual Program of Statistical Work. The SSC regularly reviews and plans improvements to its internal processes. Both the retail establishment survey and household budget survey returns are closely monitored for accuracy and essentially all compilation steps are automated in software, assuring consistent application of index calculation algorithms and ensuring very low compilation error rates. Technical issues are discussed and approved by the Scientific-Methodological Council (as authorized in the Statute on the State Statistical Committee, November 24, 2005, paragraph 18), comprising the SSC senior staff, who meet bimonthly to monitor current work and address statistical and survey issues arising. 


\subsubsection{Processes are in place to deal with quality considerations in planning the statistical program.}

A five-year Program for the Development of Statistics is maintained with advice of the Statistical Council and approved by the Council of Ministers. The current statistical development program covers 2008-2012. Statistical development programs are adjusted as required during the period they are in force. To implement the development program, the Chairman of the SSC is accountable to the President for Execution of the annual Program of Statistical Work. The SSC reports to the Statistics Council on progress with the annual statistical work program twice a year, and annually reports to the Council on the five-year development program. The SSC management structure includes a Head of Apparatus who coordinates execution of the Program of Statistical Work within the agency budget, liaising with the division heads (including the Prices Division) that directly report to the Chairman, the administrative department heads (including the Accounting Department), as well as the two Deputy Chairmen. Technical issues are discussed and approved by the ScientificMethodological Council (Statute on the State Statistical Committee, November 24, 2005, paragraph 18), comprising the SSC senior staff, whose bimonthly meetings also may develop proposals to implement new methodologies or establish new data sources and statistical products.

\section{Assurances of integrity}

\subsection{Professionalism}

\subsubsection{Statistics are produced on an impartial basis.}

Section IV of the Law on Official Statistics (as amended October 20, 2006) guarantees the professional independence of the SSC. Article 9 states that:

In order to ensure the quality of Official Statistics and retain the trust of the public therein, the organisation and implementation of the Programme [of Statistical Works] shall be governed by the principles of reliability, objectivity, relevance in present situation, statistical confidentiality and transparency.

Article 10 states further that:

The state and non-government organisations shall not interfere to the implementation of powers of the state statistical bodies and not influence the staff of the statistical authorities in the performance of their tasks.

When implementing the Programme, the state statistical bodies are autonomous and shall not seek or take instructions from state and local bodies notably in the selection of data sources, statistical 
methods, in the contents, form and time of dissemination and in the application of statistical confidentiality.

Paragraph 9 of the Statute on the State Statistical Committee (November 24, 2005) prescribes that the Chairman of the SSC is appointed directly by the President. Professional qualifications guide the recruitment and career development of staff.

The legislation governing the SSC strongly supports the independence of statistical compilation from the policy stance taken by the government, and the mission found no evidence that the SSC and the other agencies of the government have not fully adhered to the legal requirements ensuring the SSC's autonomy in statistical matters.

\subsubsection{Choices of sources and statistical techniques, as well as decisions about dissemination, are informed solely by statistical considerations.}

Article 10 of the Law provides the statutory basis for independently selecting sources and methods required to produce and disseminate CPI data:

\footnotetext{
When implementing the Programme, the state statistical bodies are autonomous and shall not seek or take instructions from state and local bodies notably in the selection of data sources, statistical methods, in the contents, form and time of dissemination and in the application of statistical confidentiality.
}

Paragraph 8 of the Statute on the State Statistics Committee (November 24, 2005) further states that:

8. The SSC of Azerbaijan has the following rights in order to carry out its duties and functions:

8.1 to publish information on the results of economic and social situation of the Republic of Azerbaijan, to work out methodological issues in the area of statistics and registration;

8.2 to select the source and method of data acquisition for carrying out works in the field of statistics, to determine the form and time of its dissemination ...

\subsubsection{The appropriate statistical entity is entitled to comment on erroneous interpretation and misuse of statistics.}

The SSC responds and has responded, as appropriate, to specific criticism of its estimates by external users, usually through the news media under its obligation set out in the Law on Official Statistics: 
The state statistical bodies shall, within the limits of their competence, be responsible for: ...

6. Providing explanation with the purpose to avoid erroneous interpretation of the statistical results by users, appearance in the mass media; [Article 6. Duties of the state statistical bodies]

\subsection{Transparency}

1.2.1 The terms and conditions under which statistics are collected, processed, and disseminated are available to the public.

The Law on Official Statistics (as amended, October 20, 2006) and the Statute on the State Statistical Committee (November 24, 2005) specify comprehensively the terms and conditions which statistics are collected, processed and disseminated.

\subsubsection{Internal governmental access to statistics prior to their release is publicly identified.}

The monthly CPI figures are released to all users simultaneously via the SSC website.

\subsubsection{Products of statistical agencies/units are clearly identified as such.}

All outputs of the SSC are clearly identified as such, including in republication of its CPI data on the website of the NBA.

\subsubsection{Advance notice is given of major changes in methodology, source data, and statistical} techniques.

There is an established pattern of annual CPI rebasing. The SSC gives notice to users of the introduction of an upcoming annual weight update in the monthly price statistics bulletin the month before the the update takes effect. Item lists are reviewed annually and may be updated. When updates are made, users are informed in the December issue of the monthly price statistics bulletin (containing January-November data) prior to implementation of the updated item list in January.

\subsection{Ethical standards}

\subsubsection{Guidelines for staff behavior are in place and are well known to the staff.}

As prescribed in Article 25 of the Law on Official Statistics states that:

The staff of the state statistical bodies shall be forbidden to perform additional work in any enterprise, institution or organisation (excluding scientific or teaching activities) or to exercise entrepreneurial activity. 
Article 26 makes clear the penalties for not observing the statistical law and Article 28 of the Law on Official Statistics staff may not divulge confidential information even after they leave the employment of the SSC.

\section{Methodological soundness}

\subsection{Concepts and definitions}

2.1.1 The overall structure in terms of concepts and definitions follows internationally accepted standards, guidelines, or good practices.

The concepts and definitions used are generally in line with internationally accepted standards and guidelines as defined by the CPI Manual.

\subsection{Scope}

2.2.1 The scope is broadly consistent with internationally accepted standards, guidelines, or good practices.

The scope of the CPI expenditure concepts coincide with household final consumption expenditures in the national accounts for all categories of goods and services (including goods and services employers provide as in-kind compensation). The SSC approach to owner occupied housing can be characterized as a partial user cost approach to imputed rentals and thus imputed rentals are in scope for the Azerbaijan CPI.

\subsection{Classification/sectorization}

2.3.1 Classification/sectorization systems used are broadly consistent with internationally accepted standards, guidelines, or good practices.

Institutional units and transactions are classified in line with the System of National Accounts 1993 (1993 SNA). The Classification of Individual Consumption by Purpose (COICOP) has been used as the classification system for the HBS since 2002 and in the CPI since 2003.

\subsection{Basis for recording}

2.4.1 Market prices are used to value flows and stocks.

The HBS and retail sales statistics, which are the basis for the CPI weights, as well as the CPI price collections themselves, measure consumption at purchasers' prices. 


\subsubsection{Recording is done on an accrual basis.}

Expenditures and price observations pertain to the years and months in which households acquired ownership of the goods or received the services the purchased.

\subsubsection{Grossing/netting procedures are broadly consistent with internationally accepted standards, guidelines, or good practices.}

The CPI weights for consumer durables, comprising the purchase of cars, furniture, appliances, and so on, are consistent with the expenditures on the same items in the national accounts. These expenditures, and the CPI weights, thus are measured as expenditures on new durables plus acquisitions less disposals of durables in secondary markets. These weights are applied to the price indexes for new durables items in the CPI.

\section{Accuracy and reliability}

\subsection{Source data}

\subsubsection{Source data are obtained from comprehensive data collection programs that take into account country-specific conditions.}

The HBS sample frame was derived from the 1999 Census of Population and is updated when enumerators find new households in their area. The coverage of the HBS frame is estimated in excess of 95 percent of all households. The survey is conducted with sample of about 4400 households each quarter, which allows the CPI weights to be updated annually. The survey covers both urban and rural areas and households are selected using the systematic random sampling technique, stratified by region. All cash expenditures are included, measured at purchasers' prices, and goods produced for own consumption are included, valued at average purchasers' prices in the region. The rental value of owneroccupied dwellings and net acquisitions of housing units are excluded. With the comprehensiveness and quarterly frequency of the HBS, ad hoc surveys are not necessary. The broad category CPI weights come from retail sales data to which HBS information is applied to produce detailed breakdowns. Although resident foreigners are not included in the HBS, the undercoverage is small, at an estimated 2.5 percent, and, in any case, the retail sales data cover the transactions of resident foreigners.

The price collections also cover not only a broad geographical range, but also a wide range of outlets. Some 9,500 outlets are covered, selected by the sales volumes observed in the SSC Trade Division Surveys. Prices are collected for 569 different products in each of the 54 CPI regions, comprising more than 130,000 quotes per month. The survey does not use point of purchase information, but the amount of household travel between CPI areas for shopping is 
thought to be small for the items having significant expenditure weight in the index. Consequently, the prices used in index calculation for each CPI region are from that region only.

Both the HBS and the retail establishment survey for the CPI use standard designs producing representative samples by of their respective target populations of households and retail establishments. It may be useful to check the judgment about the lack of shopping across CPI areas for groups of items with significant expenditure weight that could be subject to such household behavior. In some countries, the presence of "big box" and hypermarket stores can sometimes produce this phenomenon. The data for this might be produced as an add on questionnaire to the HBS.

\subsubsection{Source data reasonably approximate the definitions, scope, classifications, valuation, and time of recording required.}

The framework of the HBS is consistent with the requirements of the CPI. Prices are collected weekly for all food items in the CPI retail establishment survey, and monthly for almost all other items. Items whose price is known to change less frequently and often at a time announced in advance, such as utilities, education and health, are collected at less than monthly, and generally at annual frequency.

The HBS covers all resident private households in Azerbaijan, with the exception of those headed by non-Azerbaijani citizens. The 1999 Population Census did not contain a question regarding citizenship but the proportion excluded is estimated at 2.5 percent. Households engaged in business are included, with separate data for business activities and private consumption. Excluded are nonprivate households such as jails, military barracks and boarding schools, which is normal for such surveys. It surveys all districts within Azerbaijan which aggregate, at the publication level, to all 11 economic regions of Azerbaijan. All goods and services transactions - including the most important employer-provided benefits, which are considered compensation in-kind as well as part of household final consumption expenditure in the $1993 \mathrm{SNA}$-are covered in the HBS.

The CPI weights are derived for Azerbaijan and for each of the 11 economic regions from data that are consistent with household final consumption expenditure on the covered expenditure items, which include the production of food for own consumption and consumption from compensation in-kind. With the exception of the rental value of owneroccupied housing, the HBS expenditure data are adjusted to be consistent with national accounts household expenditure by product, which is largely based on retail sales and other 
source data. ${ }^{1}$ The index excludes the rental value of owner-occupied dwellings as well as net household purchases of houses and apartments. However, it includes expenditure on building materials. This provides a partial estimate for homeowners' housing expenses on maintenance and repair (a component of final consumption of housing services by households, when the latter is calculated by the user cost method) and major improvements to the housing unit (a component of fixed capital formation expenditure by households).

Retail establishments (outlets) are surveyed within a sample of districts across the country representing the $54 \mathrm{CPI}$ survey regions which in turn aggregate, at the publication level, to all 11 economic regions of Azerbaijan. Prices are collected from a wide range of outlets at each pricing point, so the index represents price changes for the whole of Azerbaijan and for each of 11 economic regions.

\subsubsection{Source data are timely.}

HBS data for the previous year are compiled as weights for the CPI by February of the current year and incorporated into March CPI data by the April release. Prices for the previous month are normally collected within five days of the current month.

\subsection{Assessment of source data}

3.2.1 Source data-including censuses, sample surveys, and administrative records-are routinely assessed, e.g., for coverage, sample error, response error, and nonsampling error; the results of the assessments are monitored and made available to guide statistical processes.

The HBS has high unit response from households but contains the expected amounts of item nonresponse and under-reporting on some of its more sensitive questions and in high and low income groups. This is routinely monitored. The SSC is also keeping abreast of methodological developments to deal with item nonresponse in international conferences and the professional literature. The CPI price returns are closely monitored to assess whether items have temporarily or permanently disappeared. The items sample is reviewed annually and updated as required. The retail establishment sample is continually augmented as establishments go out of business or change locations.

\footnotetext{
${ }^{1}$ This essentially offsets the 2.5 percent undercoverage of the HBS as a result of exclusion of households headed by noncitizens of Azerbaijan from its sample frame, whose source is the 1999 Population Census. The retail sales survey covers all retail expenditure in Azerbaijan.
} 


\subsection{Statistical techniques}

\subsubsection{Data compilation employs sound statistical techniques to deal with data sources.}

The HBS collects expenditure data at the COICOP five-digit level since the beginning of 2002. The CPI weights are based on household consumption as measured in the 1993 SNA, with the expenditures on housing materials and housing repair and maintenance services replacing the rent of owner-occupied dwellings.

Valuation is at purchasers' prices, including production for own consumption.

Since 2005, elementary level indexes are calculated using the geometric means of observed commodity price relatives.

A modified Laspeyres formula is used to calculate the aggregate indexes and the index is rebased during February-March of each year using weights compiled from the HBS from the previous year. It is linked to the March index.

Temporarily missing prices are imputed using the group mean approach — estimating the missing price using the average price change of the other items in the subgroup - and when a product reappears the calculation process returns to using its observed price. Imputations are made for seasonal products using the same group mean algorithm. Products that become permanently unavailable are replaced and the price change of the new (noncomparable) replacement linked in using the overlap method. Direct comparisons of prices using explicit quality adjustments are not made between the unavailable items and their noncomparable replacements. In January 2008, nine new products were introduced into the item sample and 25 old products considered no longer representative (generally on the basis of the 2007 HBS) were dropped.

The commodity specifications used for price collections are sufficient to ensure the prices of the same items are compared from month to month.

\subsubsection{Other statistical procedures (e.g., data adjustments and transformations, and statistical analysis) employ sound statistical techniques.}

The reference base of the price relatives is adjusted to the reference period of the weights when linking the annually rebased index, an internationally standard methodology.

The expenditures covered in the CPI are the same as the expenditures covered in household final consumption expenditure, except in the treatment of owner occupied housing. Expenditures on owner occupied housing in the CPI are represented by expenditures for 
maintenance and repair of the dwelling (COICOP 04.3). Expenditures for owner occupied housing in the national accounts are imputed rentals (COICOP 04.2).

There are two main approaches to measuring the imputed rent of owner-occupant households: rental equivalence and user cost. Under ideal measurement conditions they should yield similar answers.

Rental equivalence is the most direct method for compiling imputed rentals for owneroccupants. The rental value of an owner-occupied housing unit is imputed as the actual rental on a closely similar rented housing unit. This method is used in the SSC's national accounts estimate for imputed rentals, taking the average rental per rented housing unit within each district of Azerbaijan and imputing that rental to each owner-occupied unit in that district.

An alternative approach to measuring the imputed rentals of owner-occupants is the user cost method, which builds up the rental value of owned housing from its cost of ownership components. Thus, as the landlord of its own dwelling, the owner-occupant must maintain and repair it (which comprises the building materials and maintenance services items in the current SSC CPI, COICOP 04.3), and forego the income it could have earned on the financial capital invested in the unit it occupies. However, the owner also benefits from any increase in the market value of the unit for as long as it owns the dwelling, so this appreciation is subtracted from the aforementioned costs to arrive at the rent the owner would pay if it sold the unit and rented it back. In terms of the COICOP expenditure classification, this would be stated:

COICOP 04.2 Imputed rentals $=$

Real interest on funds invested in the dwelling (at the current market value of the unit)

+ COICOP 04.3 Expenditures on maintenance and repair of the dwelling.

where "Real interest on funds invested in the dwelling" is the difference between the interest foregone on invested financial capital and the expected appreciation. The SSC currently publishes and includes in the overall CPI a price index for COICOP 04.3 (Maintenance and repair of the dwelling). The SSC CPI thus takes a partial user cost approach to owneroccupied housing by covering the maintenance and repair component of the user cost of housing, a point also made in the detailed assessment of the 2002 data ROSC for Azerbaijan.

There are several options in covering imputed rent in the CPI. The CPI could use the national accounts imputed rentals estimate as the weight. This would make CPI expenditure coverage fully consistent with household final consumption expenditure. Regarding the price of imputed rent, as immediate options the CPI could continue to use the price index of 
maintenance and repair as a partial user cost estimator, or it could use a price index based on actual rentals. The recent published evidence from the CPI itself shows lower inflation in the actual rentals that would be imputed to owner households in the rental equivalence approach than the inflation in the items making up maintenance and repair. Both the maintenance and repair and actual rentals data would need assessment before using them to move the imputed rentals weight. Maintenance and repair excludes the real interest component of user cost, and the rental sample would need to be examined for representativeness of the change in the rental value of the owned housing stock. The impact on the overall index would depend on what pricing approach is taken and whether the national accounts imputed rent estimate (COICOP 04.2) is larger or smaller than the maintenance and repair estimate (COICOP 04.3) now used in the index.

The CPI Manual (Chapter 14) describes another concept for including owner-occupied housing in the CPI, sometimes called the net acquisitions approach. This concept is equivalent to the household residential capital formation concept from the national accounts. It thus contrasts with the rental equivalence and user cost approaches, which are both estimating the value of the final consumption of housing services concept in the national accounts. Although household residential capital formation is a different concept, its weight and price may be easier to measure. The weight is the net acquisitions of houses by households by type and location of housing unit plus the value of major improvements in existing housing units. This weight might be estimated from additional questions on the HBS, asking households their estimates of the goods and services they purchase for major improvements, as opposed to purchase of the same items for maintenance and repair, which already is included in the HBS. The price is the purchase price of housing units by type and location. House price change currently is thought to be significant in the larger urban areas of Azerbaijan. The SSC staff have considered a house price index as a possible future price statistics product, though as a separate, stand-alone indicator, preferring to maintain the consumption orientation of the current CPI.

Recommendation: The SSC should technically evaluate the rental equivalence and user cost approaches to covering the housing services consumption of households that own their $d$ wellings and the net acquisitions approach to households' capital formation expenditures for dwellings. While collaboration between the Price Statistics Division, National Accounts Division, and Scientific-Methodology Council would be essential, a specific advisory expert group of SSC and outside experts on the topic of housing could be useful in the evaluation as well. 


\subsection{Assessment and validation of intermediate data and statistical outputs}

\subsubsection{Intermediate results are validated against other information, where applicable.}

Changes in the CPI are cross-checked against the producer price index for comparable product categories.

The comparisons show broadly similar price developments between the indexes compared.

\subsubsection{Statistical discrepancies in intermediate data are assessed and investigated.}

Unusual price movements are constantly monitored to determine whether they arise from a data entry error, commodity misspecification, or a particular problem in the region concerned. Unusual reports are verified with the regional or district manager and, as required, with the price collector.

\subsubsection{Statistical discrepancies and other potential indicators of problems in statistical} outputs are investigated.

Unusual geographical trends are monitored to ensure they are realistic.

\subsection{Revision studies}

3.5.1 Studies and analyses of revisions are carried out routinely and used internally to inform statistical processes (see also 4.3.3).

In between rebasing, there are rare revisions to correct errors. The SSC reviews changes in the CPI weights at each annual rebasing, identifying the direction and amount of change in product shares. The SSC also reviews the item sample annually and revises if necessary.

\section{Serviceability}

\subsection{Periodicity and timeliness}

\subsubsection{Periodicity follows dissemination standards.}

The periodicity of the CPI is monthly, in line with the Special Data Dissemination Standard (SDDS) recommendations. 


\subsubsection{Timeliness follows dissemination standards.}

Monthly figures are published between the 12th and 15th of the following month which is within the SDDS requirement of one month.

\subsection{Consistency}

\subsubsection{Statistics are consistent within the dataset.}

The CPI is internally consistent in aggregation by product and by region (CPI region, economic region, and Azerbaijan).

\subsubsection{Statistics are consistent or reconcilable over a reasonable period of time.}

A consistent time series is available back to 1995, when the official CPI was first published. An unofficial series of lesser quality is available back to 1990. Methodology notes are published in the Annual Statistical Yearbook which also contains comments on trends.

\subsubsection{Statistics are consistent or reconcilable with those obtained through other data sources and/or statistical frameworks.}

The CPI is conceptually consistent with national accounts household final consumption expenditure - apart from one easily recognizable difference, owner-occupied dwellings. Reconciliation is possible accounting for this and the National Accounts Division's adjustment of comparable aggregates from the HBS to totals from the retail trade survey and certain adjustments made to correct for specific items thought to be under-reported by household on the HBS.

\subsection{Revision policy and practice}

\subsubsection{Revisions follow a regular and transparent schedule.}

The index is rebased annually and published in a range of publications.

\subsubsection{Preliminary and/or revised data are clearly identified.}

Rebasing, while technically a revision, is a normal part of CPI production and there is no need to identify data as preliminary. 


\subsubsection{Studies and analyses of revisions are made public (see also 3.5.1).}

In the April monthly bulletin introducing the reweighted index each year, a brief description is provided of items increasing in share and decreasing in share, in terms of direction but not amount.

\section{Accessibility}

\subsection{Data accessibility}

5.1.1 Statistics are presented in a way that facilitates proper interpretation and meaningful comparisons (layout and clarity of text, tables, and charts).

CPI price index data are published for 569 goods and services, and for the 11 economic regions, with charts in some publications. Some commentary is included on the changes that have occurred. No seasonally adjusted series are produced. Published expenditure estimates available from the HBS provide information relevant to the CPI weights at the two-digit COICOP level of detail.

\subsubsection{Dissemination media and format are adequate.}

Because the SSC does its own printing, the monthly publication usually appears by the 12 th of the month, earlier in electronic form (pdf). The English language tables appear in the SDDS section of the website, which is initially confusing to that group of users.

Azerbaijani language releases are timely and present impressive amounts of detail, and tables and electronic documents appear to be reasonably well organized on the SSC website. There is reasonably good support for English-language users in the number of website pages available to them, though the organization of material could be more logical.

\subsubsection{Statistics are released on a preannounced schedule.}

The statistics are produced regularly and promptly not later than the 12 th to the 15 th of the following month, taking account of weekends and holidays, often earlier. The maximum publication lag is prescribed in the Annual Statistical Program. However, the advance release calendar did not contain release dates for at least the next three months at the time of the mission, and is not updated from a "not later than" date to an exact date by the last business day of the week preceding the release, as required by the SDDS.

The SSC has published a sample "not later than" advance release calendar on its website in SDDS format, which covers an eight month period ending January 2008. The format meets 
SDDS requirements, except that the SSC does not update the release date to a specific day by the last working day of the week preceding the release. To meet SDDS requirements, the release calendar also should be current within three months of the date of release.

Recommendation: Keeping the SDDS advance release calendar current and making this site known through user outreach could help improve user confidence in the transparency and professionalism with which the CPI is compiled, and would align this practice with SDDS requirements.

\subsubsection{Statistics are made available to all users at the same time.}

Statistics are released to all users simultaneously on the SSC website.

\subsubsection{Statistics not routinely disseminated are made available upon request.}

Unpublished tables can be provided to users as long as they do not violate confidentiality (Article 22, Law on Official Statistics), but the CPI price index data are already published at a high level of detail (569 items). However, the index weights, while internally available at the same level of detail, are not available.

Article 22 of the Law on Official Statistics states that "aggregates shall comprise at least three units and the share of one unit in an aggregate must not exceed $85 \%$ of the total." The SSC decides how to ensure this disclosure criterion is met for all of its releases. HBS data are published at the two-digit COICOP level and may be available on request at higher levels of detail.

\subsection{Metadata accessibility}

5.2.1 Documentation on concepts, scope, classifications, basis of recording, data sources, and statistical techniques is available, and differences from internationally accepted standards, guidelines, or good practices are annotated.

Metadata have been posted on the IMF's GDDS website since February 2001 and were most recently updated in November 2007.

\subsubsection{Levels of detail are adapted to the needs of the intended audience.}

The monthly CPI publication contains very detailed information, but statistics at highly aggregate and intermediate levels of aggregation also are available. 


\subsection{Assistance to users}

\subsubsection{Contact points for each subject field are publicized.}

Contact persons names and telephone numbers are published in the monthly and annual prices publications.

5.3.2 Catalogs of publications, documents, and other services, including information on any charges, are widely available.

The "Catalog of Statistical Publications" is available annually in hard copy and on the SSC website. It contains contact addresses, phone numbers, and expected publication dates of SSC products. 


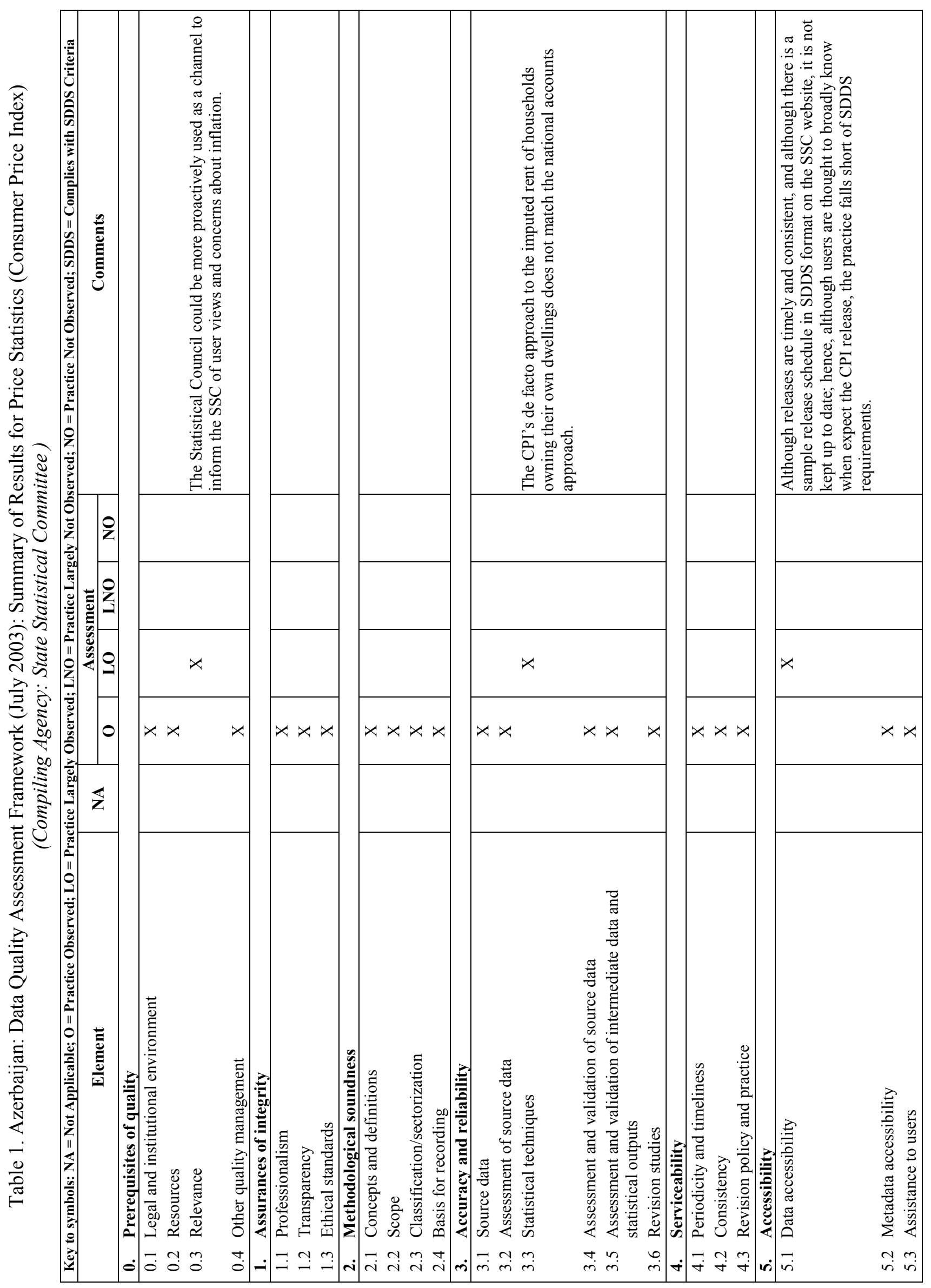




\section{Appendix I. Data Quality Assessment Framework-Generic Framework}

\begin{tabular}{|c|c|c|}
\hline $\begin{array}{c}\text { Quality } \\
\text { Dimensions }\end{array}$ & Elements & Indicators \\
\hline \multirow[t]{4}{*}{$\begin{array}{l}\text { 0. Prerequisites of } \\
\text { quality }\end{array}$} & $\begin{array}{l}\text { 0.1 Legal and institutional } \\
\text { environment-The environment } \\
\text { is supportive of statistics. }\end{array}$ & $\begin{array}{l}\text { 0.1.1 The responsibility for collecting, processing, } \\
\text { and disseminating the statistics is clearly specified. } \\
\text { 0.1.2 Data sharing and coordination among data- } \\
\text { producing agencies are adequate. } \\
\text { 0.1.3 Individual reporters' data are to be kept } \\
\text { confidential and used for statistical purposes only. } \\
0.1 .4 \text { Statistical reporting is ensured through legal } \\
\text { mandate and/or measures to encourage response. }\end{array}$ \\
\hline & $\begin{array}{l}\text { 0.2 Resources-Resources are } \\
\text { commensurate with needs of } \\
\text { statistical programs. }\end{array}$ & $\begin{array}{l}0.2 .1 \text { Staff, facilities, computing resources, and } \\
\text { financing are commensurate with statistical } \\
\text { programs. } \\
0.2 .2 \text { Measures to ensure efficient use of resources } \\
\text { are implemented. }\end{array}$ \\
\hline & $\begin{array}{l}\mathbf{0 . 3} \text { Relevance-Statistics cover } \\
\text { relevant information on the } \\
\text { subject field. }\end{array}$ & $\begin{array}{l}\text { 0.3.1 The relevance and practical utility of existing } \\
\text { statistics in meeting users' needs are monitored. }\end{array}$ \\
\hline & $\begin{array}{l}\text { 0.4 Other quality } \\
\text { management-Quality is a } \\
\text { cornerstone of statistical work. }\end{array}$ & $\begin{array}{l}0.4 .1 \text { Processes are in place to focus on quality. } \\
0.4 .2 \text { Processes are in place to monitor the quality of } \\
\text { the statistical program. } \\
\text { 0.4.3 Processes are in place to deal with quality } \\
\text { considerations in planning the statistical program. }\end{array}$ \\
\hline \multirow{3}{*}{$\begin{array}{l}\text { 1. Assurances of } \\
\text { integrity } \\
\text { The principle of } \\
\text { objectivity in the } \\
\text { collection, } \\
\text { processing, and } \\
\text { dissemination of } \\
\text { statistics is firmly } \\
\text { adhered to. }\end{array}$} & $\begin{array}{l}\text { 1.1 Professionalism-Statistical } \\
\text { policies and practices are } \\
\text { guided by professional } \\
\text { principles. }\end{array}$ & $\begin{array}{l}\text { 1.1.1 Statistics are produced on an impartial basis. } \\
\text { 1.1.2 Choices of sources and statistical techniques, } \\
\text { as well as decisions about dissemination, are } \\
\text { informed solely by statistical considerations. } \\
\text { 1.1.3 The appropriate statistical entity is entitled to } \\
\text { comment on erroneous interpretation and misuse of } \\
\text { statistics. }\end{array}$ \\
\hline & $\begin{array}{l}\text { 1.2 Transparency_Statistical } \\
\text { policies and practices are } \\
\text { transparent. }\end{array}$ & $\begin{array}{l}\text { 1.2.1 The terms and conditions under which } \\
\text { statistics are collected, processed, and disseminated } \\
\text { are available to the public. } \\
\text { 1.2.2 Internal governmental access to statistics prior } \\
\text { to their release is publicly identified. } \\
\text { 1.2.3 Products of statistical agencies/units are } \\
\text { clearly identified as such. } \\
\text { 1.2.4 Advance notice is given of major changes in } \\
\text { methodology, source data, and statistical techniques. }\end{array}$ \\
\hline & $\begin{array}{l}1.3 \text { Ethical standards-Policies } \\
\text { and practices are guided by } \\
\text { ethical standards. }\end{array}$ & $\begin{array}{l}\text { 1.3.1 Guidelines for staff behavior are in place and } \\
\text { are well known to the staff. }\end{array}$ \\
\hline
\end{tabular}




\begin{tabular}{|c|c|c|}
\hline $\begin{array}{c}\text { Quality } \\
\text { Dimensions }\end{array}$ & Elements & Indicators \\
\hline $\begin{array}{l}\text { 2. Methodological } \\
\text { soundness } \\
\text { The methodological } \\
\text { basis for the } \\
\text { statistics follows } \\
\text { internationally } \\
\text { accepted standards, } \\
\text { guidelines, or good } \\
\text { practices. }\end{array}$ & $\begin{array}{l}\text { 2.1 Concepts and definitions- } \\
\text { Concepts and definitions used } \\
\text { are in accord with } \\
\text { internationally accepted } \\
\text { statistical frameworks. } \\
2.2 \text { Scope-The scope is in } \\
\text { accord with internationally } \\
\text { accepted standards, guidelines, } \\
\text { or good practices. } \\
\text { 2.3 Classification/ } \\
\text { sectorization-Classification } \\
\text { and sectorization systems are in } \\
\text { accord with internationally } \\
\text { accepted standards, guidelines, } \\
\text { or good practices. } \\
\text { 2.4 Basis for recording-Flows } \\
\text { and stocks are valued and } \\
\text { recorded according to } \\
\text { internationally accepted } \\
\text { standards, guidelines, or good } \\
\text { practices }\end{array}$ & $\begin{array}{l}\text { 2.1.1 The overall structure in terms of concepts and } \\
\text { definitions follows internationally accepted } \\
\text { standards, guidelines, or good practices. } \\
\text { 2.2.1 The scope is broadly consistent with } \\
\text { internationally accepted standards, guidelines, or } \\
\text { good practices. } \\
\text { 2.3.1 Classification/sectorization systems used are } \\
\text { broadly consistent with internationally accepted } \\
\text { standards, guidelines, or good practices. } \\
\text { 2.4.1 Market prices are used to value flows and } \\
\text { stocks. } \\
\text { 2.4.2 Recording is done on an accrual basis. } \\
\text { 2.4.3 Grossing/netting procedures are broadly } \\
\text { consistent with internationally accepted standards, } \\
\text { guidelines, or good practices. }\end{array}$ \\
\hline $\begin{array}{l}\text { 3. Accuracy and } \\
\text { reliability } \\
\text { Source data and } \\
\text { statistical techniques } \\
\text { are sound and } \\
\text { statistical outputs } \\
\text { sufficiently portray } \\
\text { reality. }\end{array}$ & $\begin{array}{l}\text { 3.3 Statistical techniques- } \\
\text { Statistical techniques employed } \\
\text { conform to sound statistical } \\
\text { procedures. } \\
\text { 3.4 Assessment and validation } \\
\text { of intermediate data and } \\
\text { statistical outputs- } \\
\text { Intermediate results and } \\
\text { statistical outputs are regularly } \\
\text { assessed and validated. } \\
\text { 3.5 Revision studies- } \\
\text { Revisions, as a gauge of } \\
\text { reliability, are tracked and } \\
\text { mined for the information they } \\
\text { may provide. }\end{array}$ & $\begin{array}{l}\text { 3.1.1 Source data are obtained from comprehensive } \\
\text { data collection programs that take into account } \\
\text { country-specific conditions. } \\
\text { 3.1.2 Source data reasonably approximate the } \\
\text { definitions, scope, classifications, valuation, and } \\
\text { time of recording required. } \\
\text { 3.1.3 Source data are timely. } \\
\text { 3.2.1 Source data -including censuses, sample } \\
\text { surveys, and administrative records-are routinely } \\
\text { assessed, e.g., for coverage, sample error, response } \\
\text { error, and nonsampling error; the results of the } \\
\text { assessments are monitored and made available to } \\
\text { guide statistical processes. } \\
\text { 3.3.1 Data compilation employs sound statistical } \\
\text { techniques to deal with data sources. } \\
\text { 3.3.2 Other statistical procedures (e.g., data } \\
\text { adjustments and transformations, and statistical } \\
\text { analysis) employ sound statistical techniques. } \\
\text { 3.4.1 Intermediate results are validated against other } \\
\text { information, where applicable. } \\
\text { 3.4.2 Statistical discrepancies in intermediate data } \\
\text { are assessed and investigated. } \\
\text { 3.4.3 Statistical discrepancies and other potential } \\
\text { indicators or problems in statistical outputs are } \\
\text { investigated. } \\
\text { 3.5.1 Studies and analyses of revisions are carried } \\
\text { out routinely and used internally to inform statistical } \\
\text { processes (see also } 4.3 .3 \text { ). }\end{array}$ \\
\hline
\end{tabular}




\begin{tabular}{|c|c|c|}
\hline $\begin{array}{c}\text { Quality } \\
\text { Dimensions }\end{array}$ & Elements & Indicators \\
\hline $\begin{array}{l}\text { 4. Serviceability } \\
\text { Statistics, with } \\
\text { adequate periodicity } \\
\text { and timeliness, are } \\
\text { consistent and } \\
\text { follow a predictable } \\
\text { revisions policy. }\end{array}$ & $\begin{array}{l}\text { 4.1 Periodicity and } \\
\text { timeliness_Periodicity and } \\
\text { timeliness follow internationally } \\
\text { accepted dissemination } \\
\text { standards. } \\
\text { 4.2 Consistency_-Statistics are } \\
\text { consistent within the dataset, } \\
\text { over time, and with major } \\
\text { datasets. } \\
\text { 4.3 Revision policy and } \\
\text { practice-Data revisions follow } \\
\text { a regular and publicized } \\
\text { procedure. }\end{array}$ & $\begin{array}{l}\text { 4.2.1 Statistics are consistent within the dataset. } \\
\text { 4.2.2 Statistics are consistent or reconcilable over a } \\
\text { reasonable period of time. } \\
\text { 4.2.3 Statistics are consistent or reconcilable with } \\
\text { those obtained through other data sources and/or } \\
\text { statistical frameworks. } \\
\text { 4.3.1 Revisions follow a regular and transparent } \\
\text { schedule. } \\
\text { 4.3.2 Preliminary and/or revised data are clearly } \\
\text { identified. } \\
\text { 4.3.3 Studies and analyses of revisions are made } \\
\text { public (see also 3.5.1). }\end{array}$ \\
\hline $\begin{array}{l}\text { 5. Accessibility } \\
\text { Data and metadata } \\
\text { are easily available } \\
\text { and assistance to } \\
\text { users is adequate. }\end{array}$ & $\begin{array}{l}\text { 5.1 Data accessibility- } \\
\text { Statistics are presented in a } \\
\text { clear and understandable } \\
\text { manner, forms of dissemination } \\
\text { are adequate, and statistics are } \\
\text { made available on an impartial } \\
\text { basis. } \\
\text { 5.2 Metadata accessibility- } \\
\text { Up-to-date and pertinent } \\
\text { metadata are made available. } \\
\text { 5.3 Assistance to users- } \\
\text { Prompt and knowledgeable } \\
\text { support service is available. }\end{array}$ & $\begin{array}{l}\text { 5.1.1 Statistics are presented in a way that facilitates } \\
\text { proper interpretation and meaningful comparisons } \\
\text { (layout and clarity of text, tables, and charts). } \\
\text { 5.1.2 Dissemination media and format are adequate. } \\
\text { 5.1.3 Statistics are released on a preannounced } \\
\text { schedule. } \\
\text { 5.1.4 Statistics are made available to all users at the } \\
\text { same time. } \\
\text { 5.1.5 Statistics not routinely disseminated are made } \\
\text { available upon request. } \\
\text { 5.2.1 Documentation on concepts, scope, } \\
\text { classifications, basis of recording, data sources, and } \\
\text { statistical techniques is available, and differences } \\
\text { from internationally accepted standards, guidelines, } \\
\text { or good practices are annotated. } \\
\text { 5.2.2 Levels of detail are adapted to the needs of the } \\
\text { intended audience. } \\
\text { 5.3.1 Contact points for each subject field are } \\
\text { publicized. } \\
\text { 5.3.2 Catalogs of publications, documents, and other } \\
\text { services, including information on any charges, are } \\
\text { widely available. }\end{array}$ \\
\hline
\end{tabular}




\section{Appendix II. Users' Survey}

\section{Summary of results of survey of data users}

Twenty one responses were received on a nonscientific user survey of banks, nongovernmental organizations, embassies, multilateral financial institutions, the press, nonfinancial corporations, and government agencies. Broad conclusions from the survey are that a significant fraction of the surveyed users found the timeliness and periodicity of the $\mathrm{CPI}$, and the user services of the SSC in providing information on request, to be good. A number of users were not fully confident the index has adequate geographical or product coverage or, more broadly, accurately measures inflation. However, with a few exceptions, the negative responses were not specific as to the sources of disquiet about the accuracy of the index. Some users could not easily find information on the index methodology, while others could not find the data they were looking for. In general, the results of the survey highlighted the need for a communications strategy to make information on index coverage and methodology more easily available to the public, make users aware of where to obtain the information they are seeking, and to continue to conduct outreach to influential user groups to explain the CPI. This dialog may yield useful information about the sources of some users' lack of confidence in the index. 